\title{
DATA-DRIVEN PRICING DECISION IN PHARMACEUTICAL INDUSTRY: AN INTERPRETIVE STRUCTURAL MODELING APPROACH
}

\author{
JUDE JEGAN JOSEPH JEROME ${ }^{1 *}$, ARUNKUMAR. ON $^{2} \&$ VANDANA SONWANEY ${ }^{3}$ \\ ${ }^{l}$ Symbiosis Institute of Operations Management, Nashik, Symbiosis International (Deemed University), Pune, India \\ ${ }^{2}$ Assistant Professor, Symbiosis Institute of Operations Management, Nashik, Symbiosis International (Deemed University),
} Pune, India

${ }^{3}$ Professor, Symbiosis Institute of Operations Management, Nashik, Symbiosis International (Deemed University), Pune, India

ABSTRACT
Pricing is an important decision making aspect for a manufactured product. Based on the price of a product and the
required profit margin, the production of the product needs to be designed in such a way that the production cost is lesser
than the selling price. Thus, the pricing of a product has a great role to play in the production process. This research aims
to examine the relationship between all the factors and their related variables that are involved in a pricing decision for a
pharmaceutical company based on the plethora of available data. The variables and their relationships were determined
based on telephonic interviews with managers and executives from pharmaceutical manufacturing companies. Based on
their input, Interpretive Structural Modeling was done alone with MICMAC (Matrice des Impacts Croises Multiplication
Appliquee a unClassement) analysis. The research findings give a holistic picture of all the variables that go into deciding
for setting the price of a pharmaceutical drug, along with which variables to concentrate on primarily. Market share of
generic medicines, the cost of an active ingredient, and the regulations of a country have been found greatly influence the
pricing strategy for a pharmaceutical drug.
KEYWORDS: Pricing Decision, Pricing Strategy, Pharmaceutical Industry, Interpretive Structural Modeling, MICMAC

Received: Jun 10, 2020; Accepted: Jun 30, 2020; Published: Aug 01, 2020; Paper Id.: IJMPERDJUN2020557

\section{INTRODUCTION}

The production process that occurs in a pharmaceutical firm depends greatly on a robust supply chain. This supply chain, supported by many parties, aid in the process of manufacture and distribution of a product in the market. Thus, this supply chain ensures that the demand in the market is serviced by the supply.

Pharmaceutical products, however, cannot be solely priced based on the complexity of their supply chain. There are various laws and regulations in place that ensure that drugs reach people of all groups. Moreover, the price of a pharmaceutical drug is heavily dependent on the patent period, which is in turn dependent on the regulations of the country the drug is researched in. Post the patent period, the drug can easily be manufactured by competitors as well as generic medicine companies, thus forcing the founding firm to lower the prices to stay competitive in the market. The brand name of a drug has a suitable role to play as well. People often tend to prefer drugs from a certain brand over others or even over the generic versions due to the brand loyalty that has been built over their years of consumption. Thus, when it comes to pricing a drug, organizations adopt various techniques that use multiple variables and factors to arrive at a price at which the drug can be sold. This study uses Interpretive Structure Modeling (ISM) to analyze the relationship between these variables to come up with a model that will use 
is designing a strategy that can be used while deciding on the price of a pharmaceutical product.

The result of this study is expected to give a holistic view of all the variables that can be considered while pricing a pharmaceutical product, their effects on each other, and help decision-makers arrive at decisions easily.

This paper starts by analyzing literature for the factors and their related variables. Post this, the relationship between the variables is found through a survey. ISM is done for these variables, followed by MIMAC analysis. Suitable conclusions are drawn for the model and the importance of variables is predicted.

\section{LITERATURE REVIEW}

Modeling techniques have a great role to play in helping executives arrive at decisions based on various scenarios. One of the most famous modelings is the Interpretive Structural Modeling technique (ISM). Ukyet al. (2018) used this technique to find out the factors that are important in corporate IT governance. According to their study, the ISM approach has many advantages over the traditional TOPSIS and AHP approach, as ISM deals with hierarchical relationships as well. However, for this to work the data that needs to be considered has to be accurate.

When deciding the price of a pharmaceutical product, the first factor considered is the Cost Structure. According to Imamuddin et al. (2014), the cost structure is one of the key factors that decide the price of the product. According to their study, this factor can be broken down into further into Cost of Active Ingredient, Cost of Other Ingredients, Cost of Packaging Material, and Cost of Manufacturing. All these variables contribute to the Cost Structure, which in turn contributes to the price.

The next factor that comes into play is the Research and Development (R\&D) cost. According to a study conducted by Vittorio and Giovanni (2003), the R\&D cost can be broken down into five variables, namely, "Number and Quality of Potential Targets", "Failure Rate of Targets", "Number of Patients involves in Clinical Trials", "Speed of Screening", and "Overall length of Trials". R\&D happens over a long period for a drug, and hence this factor strongly influences the price of the drug as well.

According to Renganathan et al. (2016), the demand for a drug in the market is also a contributing factor towards the pricing decision of that drug. When a drug is in high demand in the market, it means that the consumers are ready to pay higher prices for it, and hence the price of the drug can be set accordingly. The converse of this case is true as well. A study conducted by Christine et al. (2012) shows that this demand is influence by two variables: "Price Sensitivity" and "Level of Asymmetric information between patient and subscriber". The latter refers to the scenario where a medical practitioner prescribes only a certain drug, thus ensuring that it is in demand always. Another study by Pieter and Steven (2012) suggests that "Market share of Generic Medicines" will also greatly affect the demand of a drug in the market. Galina et al. (2019) suggest that the previous sales of a product also drive its future demand, as trends in the sales of the product can help identify its necessity in the market.

One of the most popular techniques of arriving at the price of a pharmaceutical drug is External Price Referencing (EPR). This technique involves a comparison of the price of a pharmaceutical drug in similar countries. According to Sabine et al. (2019), this technique is used as a starting point for fixing the price of the pharmaceutical drug. The study conducted by Christine et al. (2012) suggests that this factor is governed by three variables: "Gross Domestic Product (GDP) per Capita", "Regulations and their strength", and "Number of Countries in the reference basket". 
Thus, the price of a pharmaceutical drug can be decided based on the factors and their variables mentioned above. However, even with all the variables defined, the possibility of arriving at a price occurs only with the presence of data. Decisions for the price are made based on the data that are provided, hence right data becomes extremely important. According to Stefan et al. (2019), five key factors influence the level of data-driven decision making in an organization. They are "Firm Environment", “Competition", "Executive Commitment", "Interdepartmental Dynamics", and “Organizational Structure”.

The pieces of literature that have been analyzed provide the relationship of the variables of a single factor with one another. This study will aim to bridge this gap by analyzing the relationship of all factors and their variables with each other.

\section{METHODOLOGY}

After the factors and their variables are identified, the next step was to create a questionnaire that will help ascertain the relationship of the variables to their factors. The questionnaire also helped in ascertaining the relationship that exists between all the variables considered. For this study, a total of 21 variables were considered. Telephonic interviews were conducted with managers and executives from a few top pharmaceutical companies for this study.

Interpretive Structural Modeling (ISM) is an 8 step process. The steps are given in brief as follows:

- Step 1: Identification of the factor and their related variables. This has been summarized in table 1.

Table 1: Summary of Factors and their corresponding Variables

\begin{tabular}{|c|c|c|c|}
\hline Factor & Variables & Depiction & Reference \\
\hline \multirow{4}{*}{ Cost Structure } & Cost of active ingredient & $\mathrm{A}$ & \multirow{4}{*}{$\begin{array}{l}\text { Imamuddin et al. } \\
(2014)\end{array}$} \\
\hline & Cost of other ingredients & $\mathrm{B}$ & \\
\hline & Cost of packaging material & $\mathrm{C}$ & \\
\hline & Cost of manufacturing & $\mathrm{D}$ & \\
\hline \multirow{4}{*}{ Demand } & Price Sensitivity & $\mathrm{E}$ & \multirow[b]{2}{*}{ Christine et al. (2012) } \\
\hline & $\begin{array}{l}\text { Level of asymmetric information between } \\
\text { patient and prescriber }\end{array}$ & $\mathrm{F}$ & \\
\hline & Market Share of Generic Medicines & G & $\begin{array}{l}\text { Pieter and Steven } \\
(2012)\end{array}$ \\
\hline & Previous Sales & $\mathrm{H}$ & Galina et al. (2019) \\
\hline \multirow{5}{*}{ R\&D Cost } & Number and Quality of Potential Targets & $\mathrm{I}$ & \multirow{5}{*}{$\begin{array}{l}\text { Vittorio and Giovanni } \\
(2003)\end{array}$} \\
\hline & Failure Rate of Targets & $\mathrm{J}$ & \\
\hline & Number of Patients Involved in Clinical Trials & $\mathrm{K}$ & \\
\hline & Speed of Screening & $\mathrm{L}$ & \\
\hline & Overall length of trials & $\mathrm{M}$ & \\
\hline \multirow{3}{*}{$\begin{array}{l}\text { External Pricing } \\
\text { Referencing }\end{array}$} & GDP per capita & $\mathrm{N}$ & \multirow{3}{*}{ Christine et al. (2012) } \\
\hline & Regulations & $\mathrm{O}$ & \\
\hline & Number of countries in reference basket & $\mathrm{P}$ & \\
\hline \multirow{5}{*}{$\begin{array}{l}\text { Data-Driven Decision } \\
\text { Capability }\end{array}$} & Firm Environment & Q & \multirow{5}{*}{ Stefan et al. (2019) } \\
\hline & Competition & $\mathrm{R}$ & \\
\hline & Executive Commitment & $\mathrm{S}$ & \\
\hline & Interdepartmental Dynamics & $\mathrm{T}$ & \\
\hline & Organizational Structure & $\mathrm{U}$ & \\
\hline
\end{tabular}

- Step 2: Creation of a relationship between these variables using a survey.

- $\quad$ Step 3: Creation of a Structural Self-Interaction Matrix (SSIM). 
- Step 4: Formulation of the SSIM Reachability Matrix. This matrix will help us study the transitivity of the relationships.

- $\quad$ Step 5: Partitioning of the SSIM Reachability Matrix into different levels.

- Step 6: Creation of a Digraph and the removal of transitive relationships.

- Step 7: Conversion of Digraph into the ISM model form.

- $\quad$ Step 8: Checking of the ISM Model to see if modifications need to be made.

\section{DATA ANALYSIS}

Post-study of literature and the survey, an SSIM was created. This has been depicted in Table 2. The following nomenclature has been followed for designing the SSIM.

- $\quad V$ : Factor 'i' influences factor ' $\mathrm{j}$ '

- $A$ : Factor 'j' influences factor 'i'

- $X$ : Factor 'i' and factor 'j' influence each other

- $O$ : Factor 'i' and factor 'j' do not influence each other

Table 2: Structural Self-Interaction Matrix (SSIM)

\begin{tabular}{|c|c|c|c|c|c|c|c|c|c|c|c|c|c|c|c|c|c|c|c|c|c|}
\hline & $\mathbf{U}$ & $\mathbf{T}$ & $\mathbf{S}$ & $\mathbf{R}$ & Q & $\mathbf{P}$ & $\mathbf{O}$ & $\mathbf{N}$ & $\overline{\mathbf{M}}$ & $\mathbf{L}$ & $\mathbf{K}$ & $\mathbf{J}$ & I & $\mathbf{H}$ & G & $\mathbf{F}$ & $\mathbf{E}$ & D & $\mathbf{C}$ & B & $\mathbf{A}$ \\
\hline $\mathbf{A}$ & $\mathrm{O}$ & $\mathrm{O}$ & $\mathrm{O}$ & $\mathrm{O}$ & $\mathrm{O}$ & $\mathrm{O}$ & A & $\mathrm{O}$ & $\mathrm{A}$ & $\mathrm{O}$ & $\mathrm{O}$ & $\mathrm{O}$ & $\mathrm{O}$ & $\mathrm{V}$ & X & $\mathrm{O}$ & $\mathrm{O}$ & $\mathrm{X}$ & $\mathrm{O}$ & $\mathrm{V}$ & $\mathrm{X}$ \\
\hline B & $\mathrm{O}$ & $\mathrm{O}$ & $\mathrm{O}$ & $\mathrm{O}$ & $\mathrm{O}$ & $\mathrm{O}$ & $\mathrm{A}$ & $\mathrm{O}$ & $\mathrm{A}$ & $\mathrm{O}$ & $\mathrm{O}$ & $\mathrm{O}$ & $\mathrm{O}$ & $\mathrm{V}$ & $\mathrm{V}$ & $\mathrm{O}$ & $\mathrm{O}$ & $\mathrm{X}$ & $\mathrm{V}$ & $X$ & \\
\hline $\mathbf{C}$ & $\mathrm{O}$ & $\mathrm{O}$ & $\mathrm{O}$ & $\mathrm{O}$ & $\mathrm{O}$ & $\mathrm{O}$ & $\mathrm{A}$ & $\mathrm{O}$ & $\mathrm{O}$ & $\mathrm{O}$ & $\mathrm{O}$ & $\mathrm{O}$ & $\mathrm{O}$ & $\mathrm{V}$ & $\mathrm{O}$ & $\mathrm{O}$ & $\mathrm{O}$ & $\mathrm{O}$ & $\mathrm{X}$ & & \\
\hline D & $\mathrm{O}$ & $\mathrm{O}$ & $\mathrm{O}$ & $\mathrm{O}$ & $\mathrm{O}$ & $\mathrm{O}$ & $\mathrm{A}$ & $\mathrm{O}$ & $\mathrm{O}$ & $\mathrm{O}$ & $\mathrm{O}$ & $\mathrm{O}$ & $\mathrm{O}$ & $\mathrm{V}$ & $\mathrm{O}$ & $\mathrm{O}$ & $\mathrm{O}$ & $X$ & & & \\
\hline $\mathbf{E}$ & $\mathrm{O}$ & $\mathrm{O}$ & $\mathrm{O}$ & $\mathrm{A}$ & $\mathrm{A}$ & $\mathrm{O}$ & $\mathrm{O}$ & $\mathrm{O}$ & $\mathrm{O}$ & $\mathrm{O}$ & $\mathrm{O}$ & $\mathrm{O}$ & $\mathrm{O}$ & $\mathrm{A}$ & $\mathrm{A}$ & $\mathrm{A}$ & $\mathrm{X}$ & & & & \\
\hline $\mathbf{F}$ & $\mathrm{O}$ & $\mathrm{O}$ & $\mathrm{O}$ & $\mathrm{A}$ & $\mathrm{A}$ & $\mathrm{O}$ & $\mathrm{O}$ & $\mathrm{O}$ & $\mathrm{O}$ & $\mathrm{O}$ & $\mathrm{O}$ & $\mathrm{O}$ & $\mathrm{O}$ & $\mathrm{O}$ & $X$ & $\bar{X}$ & & & & & \\
\hline $\mathbf{G}$ & $\mathrm{O}$ & $\mathrm{O}$ & A & $\mathrm{A}$ & A & $\mathrm{O}$ & $X$ & $\mathrm{O}$ & $\mathrm{V}$ & V & $\mathrm{O}$ & $\mathrm{O}$ & $\mathrm{O}$ & A & $X$ & & & & & & \\
\hline $\mathbf{H}$ & $\mathrm{A}$ & $\mathrm{A}$ & $\mathrm{A}$ & $\mathrm{A}$ & $\mathrm{A}$ & $\mathrm{O}$ & $\mathrm{A}$ & $\mathrm{A}$ & $\mathrm{O}$ & $\mathrm{O}$ & $\mathrm{O}$ & $\mathrm{O}$ & $\mathrm{O}$ & $\mathrm{X}$ & & & & & & & \\
\hline $\mathbf{I}$ & $\mathrm{O}$ & $\mathrm{O}$ & $\mathrm{O}$ & $\mathrm{O}$ & $\mathrm{O}$ & $\mathrm{O}$ & $\mathrm{O}$ & $\mathrm{O}$ & $\mathrm{V}$ & $\mathrm{V}$ & $\mathrm{O}$ & $X$ & $X$ & & & & & & & & \\
\hline $\mathbf{J}$ & $\mathrm{O}$ & $\mathrm{O}$ & $\mathrm{O}$ & $\mathrm{O}$ & $\mathrm{O}$ & $\mathrm{O}$ & $\mathrm{O}$ & $\mathrm{O}$ & $\mathrm{V}$ & V & $\mathrm{O}$ & $X$ & & & & & & & & & \\
\hline $\mathbf{K}$ & $\mathrm{O}$ & $\mathrm{O}$ & $\mathrm{O}$ & $\mathrm{O}$ & $\mathrm{O}$ & $\mathrm{O}$ & $\mathrm{A}$ & $\mathrm{O}$ & $\mathrm{V}$ & $\mathrm{V}$ & $\mathrm{X}$ & & & & & & & & & & \\
\hline $\mathbf{L}$ & $\mathrm{O}$ & $\mathrm{A}$ & $\mathrm{O}$ & $\mathrm{O}$ & $\mathrm{O}$ & $\mathrm{O}$ & $\mathrm{A}$ & $\mathrm{V}$ & $\mathrm{X}$ & $\mathrm{X}$ & & & & & & & & & & & \\
\hline $\mathbf{M}$ & A & $\mathrm{O}$ & $\mathrm{O}$ & $\mathrm{A}$ & $\mathrm{O}$ & $\mathrm{O}$ & A & $\mathrm{O}$ & $X$ & & & & & & & & & & & & \\
\hline $\mathbf{N}$ & $\mathrm{O}$ & $\mathrm{O}$ & $\mathrm{O}$ & $\mathrm{O}$ & $\mathrm{O}$ & $\mathrm{O}$ & $\mathrm{O}$ & $\mathrm{X}$ & & & & & & & & & & & & & \\
\hline $\mathbf{O}$ & $\mathrm{A}$ & $\mathrm{O}$ & $\mathrm{A}$ & $\mathrm{O}$ & $\mathrm{O}$ & $\mathrm{O}$ & $\mathrm{X}$ & & & & & & & & & & & & & & \\
\hline $\mathbf{P}$ & $\mathrm{A}$ & $\mathrm{A}$ & $\mathrm{A}$ & $\mathrm{O}$ & $\mathrm{O}$ & $\mathrm{X}$ & & & & & & & & & & & & & & & \\
\hline $\mathbf{Q}$ & $\mathrm{A}$ & $\mathrm{X}$ & $\mathrm{X}$ & $\mathrm{X}$ & $\mathrm{X}$ & & & & & & & & & & & & & & & & \\
\hline $\mathbf{R}$ & $\mathrm{O}$ & $\mathrm{O}$ & $\mathrm{O}$ & $\mathrm{X}$ & & & & & & & & & & & & & & & & & \\
\hline $\mathbf{S}$ & $X$ & $\mathrm{X}$ & $X$ & & & & & & & & & & & & & & & & & & \\
\hline $\mathbf{T}$ & $\mathrm{X}$ & $\mathrm{X}$ & & & & & & & & & & & & & & & & & & & \\
\hline $\mathbf{U}$ & $X$ & & & & & & & & & & & & & & & & & & & & \\
\hline
\end{tabular}

Post this, the SSIM Reachability Matrix is created. It is a binary matrix as shown in Table 3. 
Table 3: The Reachability Matrix

\begin{tabular}{|c|c|c|c|c|c|c|c|c|c|c|c|c|c|c|c|c|c|c|c|c|c|}
\hline & $\mathbf{U}$ & $\mathbf{T}$ & $\mathbf{S}$ & $\mathbf{R}$ & $\mathbf{Q}$ & $\mathbf{P}$ & $\mathbf{O}$ & $\mathbf{N}$ & $\mathbf{M}$ & $\mathbf{L}$ & $\mathbf{K}$ & $\mathbf{J}$ & $\mathbf{I}$ & $\mathbf{H}$ & $\mathbf{G}$ & $\mathbf{F}$ & $\mathbf{E}$ & $\mathbf{D}$ & $\mathbf{C}$ & $\mathbf{B}$ & $\mathbf{A}$ \\
\hline $\mathbf{A}$ & 0 & 0 & 0 & 0 & 0 & 0 & 0 & 0 & 0 & 0 & 0 & 0 & 0 & 1 & 1 & 0 & 0 & 1 & 0 & 1 & 1 \\
\hline $\mathbf{B}$ & 0 & 0 & 0 & 0 & 0 & 0 & 0 & 0 & 0 & 0 & 0 & 0 & 0 & 1 & 1 & 0 & 0 & 1 & 1 & 1 & 0 \\
\hline $\mathbf{C}$ & 0 & 0 & 0 & 0 & 0 & 0 & 0 & 0 & 0 & 0 & 0 & 0 & 0 & 1 & 0 & 0 & 0 & 0 & 1 & 0 & 0 \\
\hline $\mathbf{D}$ & 0 & 0 & 0 & 0 & 0 & 0 & 0 & 0 & 0 & 0 & 0 & 0 & 0 & 1 & 0 & 0 & 0 & 1 & 0 & 1 & 1 \\
\hline $\mathbf{E}$ & 0 & 0 & 0 & 0 & 0 & 0 & 0 & 0 & 0 & 0 & 0 & 0 & 0 & 0 & 0 & 0 & 1 & 0 & 0 & 0 & 0 \\
\hline $\mathbf{F}$ & 0 & 0 & 0 & 0 & 0 & 0 & 0 & 0 & 0 & 0 & 0 & 0 & 0 & 0 & 1 & 1 & 1 & 0 & 0 & 0 & 0 \\
\hline $\mathbf{G}$ & 0 & 0 & 0 & 0 & 0 & 0 & 1 & 0 & 1 & 1 & 0 & 0 & 0 & 0 & 1 & 1 & 1 & 0 & 0 & 0 & 1 \\
\hline $\mathbf{H}$ & 0 & 0 & 0 & 0 & 0 & 0 & 0 & 0 & 0 & 0 & 0 & 0 & 0 & 1 & 1 & 0 & 1 & 0 & 0 & 0 & 0 \\
\hline $\mathbf{I}$ & 0 & 0 & 0 & 0 & 0 & 0 & 0 & 0 & 1 & 1 & 0 & 1 & 1 & 0 & 0 & 0 & 0 & 0 & 0 & 0 & 0 \\
\hline $\mathbf{J}$ & 0 & 0 & 0 & 0 & 0 & 0 & 0 & 0 & 1 & 1 & 0 & 1 & 1 & 0 & 0 & 0 & 0 & 0 & 0 & 0 & 0 \\
\hline $\mathbf{K}$ & 0 & 0 & 0 & 0 & 0 & 0 & 0 & 0 & 1 & 1 & 1 & 0 & 0 & 0 & 0 & 0 & 0 & 0 & 0 & 0 & 0 \\
\hline $\mathbf{L}$ & 0 & 0 & 0 & 0 & 0 & 0 & 0 & 1 & 1 & 1 & 0 & 0 & 0 & 0 & 0 & 0 & 0 & 0 & 0 & 0 & 0 \\
\hline $\mathbf{M}$ & 0 & 0 & 0 & 0 & 0 & 0 & 0 & 0 & 1 & 1 & 0 & 0 & 0 & 0 & 0 & 0 & 0 & 0 & 0 & 0 & 1 \\
\hline $\mathbf{N}$ & 0 & 0 & 0 & 0 & 0 & 0 & 0 & 1 & 0 & 0 & 0 & 0 & 0 & 1 & 0 & 0 & 0 & 0 & 0 & 0 & 0 \\
\hline $\mathbf{O}$ & 0 & 0 & 0 & 0 & 0 & 0 & 1 & 0 & 1 & 1 & 1 & 0 & 0 & 1 & 1 & 0 & 0 & 1 & 1 & 1 & 1 \\
\hline $\mathbf{P}$ & 0 & 0 & 0 & 0 & 0 & 1 & 0 & 0 & 0 & 0 & 0 & 0 & 0 & 0 & 0 & 0 & 0 & 0 & 0 & 0 & 0 \\
\hline $\mathbf{Q}$ & 0 & 1 & 1 & 1 & 1 & 0 & 0 & 0 & 0 & 0 & 0 & 0 & 0 & 1 & 1 & 1 & 1 & 0 & 0 & 0 & 0 \\
\hline $\mathbf{R}$ & 0 & 0 & 0 & 1 & 1 & 0 & 0 & 0 & 1 & 0 & 0 & 0 & 0 & 1 & 1 & 1 & 1 & 0 & 0 & 0 & 0 \\
\hline $\mathbf{S}$ & 1 & 1 & 1 & 0 & 1 & 1 & 1 & 0 & 0 & 0 & 0 & 0 & 0 & 1 & 1 & 0 & 0 & 0 & 0 & 0 & 0 \\
\hline $\mathbf{T}$ & 1 & 1 & 1 & 0 & 1 & 1 & 0 & 0 & 0 & 1 & 0 & 0 & 0 & 1 & 0 & 0 & 0 & 0 & 0 & 0 & 0 \\
\hline $\mathbf{U}$ & 1 & 1 & 1 & 0 & 1 & 1 & 1 & 0 & 1 & 0 & 0 & 0 & 0 & 1 & 0 & 0 & 0 & 0 & 0 & 0 & 0 \\
\hline
\end{tabular}

Once the reachability matrix is created, the transitivity rule is applied. Transitivity rules state that if ' $A$ ' influences ' $\mathrm{B}$ ' and ' $\mathrm{B}$ ' influences ' $\mathrm{C}$ ', then ' $\mathrm{A}$ ' would influence ' $\mathrm{C}$ '. Based on this rule, the final reachability matrix is created. This has been done with the help of the ISM package of R software. This matrix is shown in Table 4 . The values that have been modified post the application of the transitivity rule are written in italics.

The Driving Power is calculated as the sum of all the cells in that row for that particular variable. This will help us in ranking the variables according to various levels. The Dependence is calculated as the sum of the elements in that column for that particular variable.

Table 4: Final Reachability Matrix

\begin{tabular}{|c|c|c|c|c|c|c|c|c|c|c|c|c|c|c|c|c|c|c|c|c|c|c|}
\hline & $\mathbf{A}$ & $\mathbf{B}$ & $\mathbf{C}$ & $\mathbf{D}$ & $\mathbf{E}$ & $\mathbf{F}$ & $\mathbf{G}$ & $\mathbf{H}$ & $\mathbf{I}$ & $\mathbf{J}$ & $\mathbf{K}$ & $\mathbf{L}$ & $\mathbf{M}$ & $\mathbf{N}$ & $\mathbf{O}$ & $\mathbf{P}$ & $\mathbf{Q}$ & $\mathbf{R}$ & $\mathbf{S}$ & $\mathbf{T}$ & $\mathbf{U}$ & $\begin{array}{c}\text { Drivin } \\
\mathbf{g} \\
\text { Power }\end{array}$ \\
\hline $\mathbf{A}$ & 1 & 1 & 1 & 1 & $l$ & $l$ & 1 & 1 & 0 & 0 & 0 & $l$ & 1 & 0 & 1 & 0 & 0 & 0 & 0 & 0 & 0 & 11 \\
\hline $\mathbf{B}$ & 1 & 1 & 1 & 1 & 1 & 1 & 1 & 1 & 0 & 0 & 0 & 1 & 1 & 0 & 1 & 0 & 0 & 0 & 0 & 0 & 0 & 11 \\
\hline $\mathbf{C}$ & 0 & 0 & 1 & 0 & 1 & 0 & 1 & 1 & 0 & 0 & 0 & 0 & 0 & 0 & 0 & 0 & 0 & 0 & 0 & 0 & 0 & 4 \\
\hline $\mathbf{D}$ & 1 & 1 & 1 & 1 & 1 & 0 & 1 & 1 & 0 & 0 & 0 & 0 & 0 & 0 & 0 & 0 & 0 & 0 & 0 & 0 & 0 & 7 \\
\hline $\mathbf{E}$ & 0 & 0 & 0 & 0 & 1 & 0 & 0 & 0 & 0 & 0 & 0 & 0 & 0 & 0 & 0 & 0 & 0 & 0 & 0 & 0 & 0 & 1 \\
\hline $\mathbf{F}$ & 1 & 0 & 0 & 0 & 1 & 1 & 1 & 0 & 0 & 0 & 0 & 1 & 1 & 0 & 1 & 0 & 0 & 0 & 0 & 0 & 0 & 7 \\
\hline $\mathbf{G}$ & 1 & 1 & 1 & 1 & 1 & 1 & 1 & 1 & 0 & 0 & 1 & 1 & 1 & 1 & 1 & 0 & 0 & 0 & 0 & 0 & 0 & 13 \\
\hline $\mathbf{H}$ & 1 & 0 & 0 & 0 & 1 & 1 & 1 & 1 & 0 & 0 & 0 & 1 & 1 & 0 & 1 & 0 & 0 & 0 & 0 & 0 & 0 & 8 \\
\hline $\mathbf{I}$ & 1 & 0 & 0 & 0 & 0 & 0 & 0 & 0 & 1 & 1 & 0 & 1 & 1 & 1 & 0 & 0 & 0 & 0 & 0 & 0 & 0 & 6 \\
\hline $\mathbf{J}$ & 1 & 0 & 0 & 0 & 0 & 0 & 0 & 0 & 1 & 1 & 0 & 1 & 1 & 1 & 0 & 0 & 0 & 0 & 0 & 0 & 0 & 6 \\
\hline $\mathbf{K}$ & 1 & 0 & 0 & 0 & 0 & 0 & 0 & 0 & 0 & 0 & 1 & 1 & 1 & 1 & 0 & 0 & 0 & 0 & 0 & 0 & 0 & 5 \\
\hline $\mathbf{L}$ & 1 & 0 & 0 & 0 & 0 & 0 & 0 & 1 & 0 & 0 & 0 & 1 & 1 & 1 & 0 & 0 & 0 & 0 & 0 & 0 & 0 & 5 \\
\hline $\mathbf{M}$ & 1 & 1 & 0 & 1 & 0 & 0 & 1 & 1 & 0 & 0 & 0 & 1 & 1 & 1 & 0 & 0 & 0 & 0 & 0 & 0 & 0 & 8 \\
\hline $\mathbf{N}$ & 0 & 0 & 0 & 0 & 1 & 0 & 1 & 1 & 0 & 0 & 0 & 0 & 0 & 1 & 0 & 0 & 0 & 0 & 0 & 0 & 0 & 4 \\
\hline $\mathbf{O}$ & 1 & 1 & 1 & 1 & 1 & 1 & 1 & 1 & 0 & 0 & 1 & 1 & 1 & 1 & 1 & 0 & 0 & 0 & 0 & 0 & 0 & 13 \\
\hline $\mathbf{P}$ & 0 & 0 & 0 & 0 & 0 & 0 & 0 & 0 & 0 & 0 & 0 & 0 & 0 & 0 & 0 & 1 & 0 & 0 & 0 & 0 & 0 & 1 \\
\hline $\mathbf{Q}$ & 1 & 0 & 0 & 0 & 1 & 1 & 1 & 1 & 0 & 0 & 0 & 1 & 1 & 0 & 1 & 1 & 1 & 1 & 1 & 1 & 1 & 14 \\
\hline
\end{tabular}




\begin{tabular}{|c|c|c|c|c|c|c|c|c|c|c|c|c|c|c|c|c|c|c|c|c|c|c|}
\hline $\mathbf{R}$ & 1 & 0 & 0 & 0 & 1 & 1 & 1 & 1 & 0 & 0 & 0 & 1 & 1 & 0 & 1 & 0 & 1 & 1 & 1 & 1 & 0 & 12 \\
\hline $\mathbf{S}$ & 1 & 1 & 1 & 1 & 1 & 1 & 1 & 1 & 0 & 0 & 1 & 1 & 1 & 0 & 1 & 1 & 1 & 1 & 1 & 1 & 1 & 18 \\
\hline $\mathbf{T}$ & 0 & 0 & 0 & 0 & 1 & 1 & 1 & 1 & 0 & 0 & 0 & 1 & 1 & 1 & 1 & 1 & 1 & 1 & 1 & 1 & 1 & 14 \\
\hline $\mathbf{U}$ & 1 & 1 & 1 & 1 & 1 & 1 & 1 & 1 & 0 & 0 & 1 & 1 & 1 & 0 & 1 & 1 & 1 & 1 & 1 & 1 & 1 & 18 \\
\hline $\begin{array}{c}\text { Dependenc } \\
\text { e }\end{array}$ & 1 & 6 & 8 & 8 & 1 & 1 & 1 & 1 & 2 & 2 & 5 & 1 & 1 & 9 & 1 & 5 & 5 & 5 & 5 & 5 & 4 & \\
\hline
\end{tabular}

The final reachability matrix obtained above contains the driving power of all the variables in the pricing decision of the pharmaceutical drug. With this data, the variables are partitioned into various levels. The first level will contain the variables with the lowest driving power, the second level will contain the variables with the second-lowest driving power, and so on.

Table 5: The Level Matrix

\begin{tabular}{|c|c|c|}
\hline Variables & Driving Power & Level \\
\hline E, P & 1 & 1 \\
\hline C, N & 4 & 2 \\
\hline K, L & 5 & 3 \\
\hline I, J & 6 & 4 \\
\hline D, F & 7 & 5 \\
\hline H, M & 8 & 6 \\
\hline A, B & 11 & 7 \\
\hline R & 12 & 8 \\
\hline G, O & 13 & 9 \\
\hline Q, T & 14 & 10 \\
\hline S, U & 18 & 11 \\
\hline
\end{tabular}

Based on the data of the Driving Power and Dependence for all the variables, MICMAC Analysis is done. Matrice des Impacts Croises Multiplication Appliquee a unClassement, or MICMAC, is done to identify the variables which are key to the system, based on their driving power and their dependence. The MICMAC analysis for our study is depicted in Image 1. Based on the quadrants each of the variables belong to, suitable strategies can be formulated. The autonomous variables are ones that do not have much effect on the system. The driving variables are the ones who will influence the pricing decision the most.

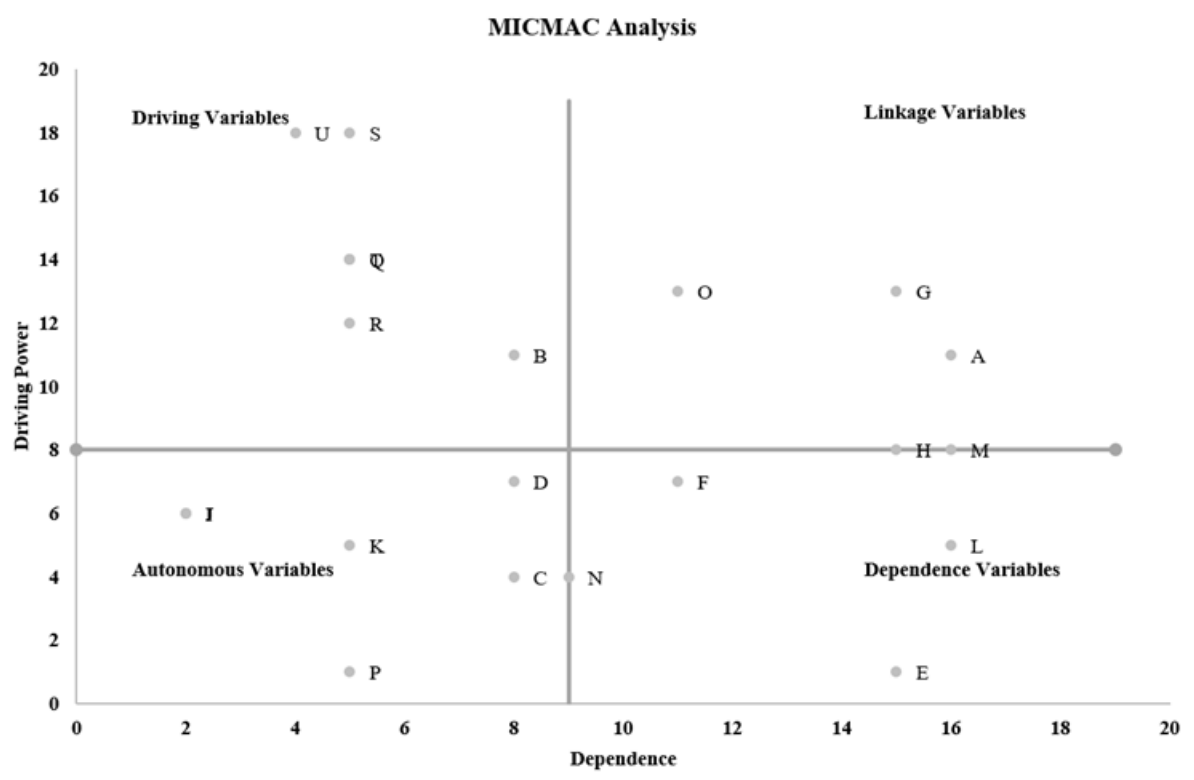

Figure 1: MIMAC Analysis. 


\section{RESULTS}

Based on the ISM conducted above for data-driven pricing decisions in the pharmaceutical industry, and the overall model can be formed. This model has been depicted in Image 2.

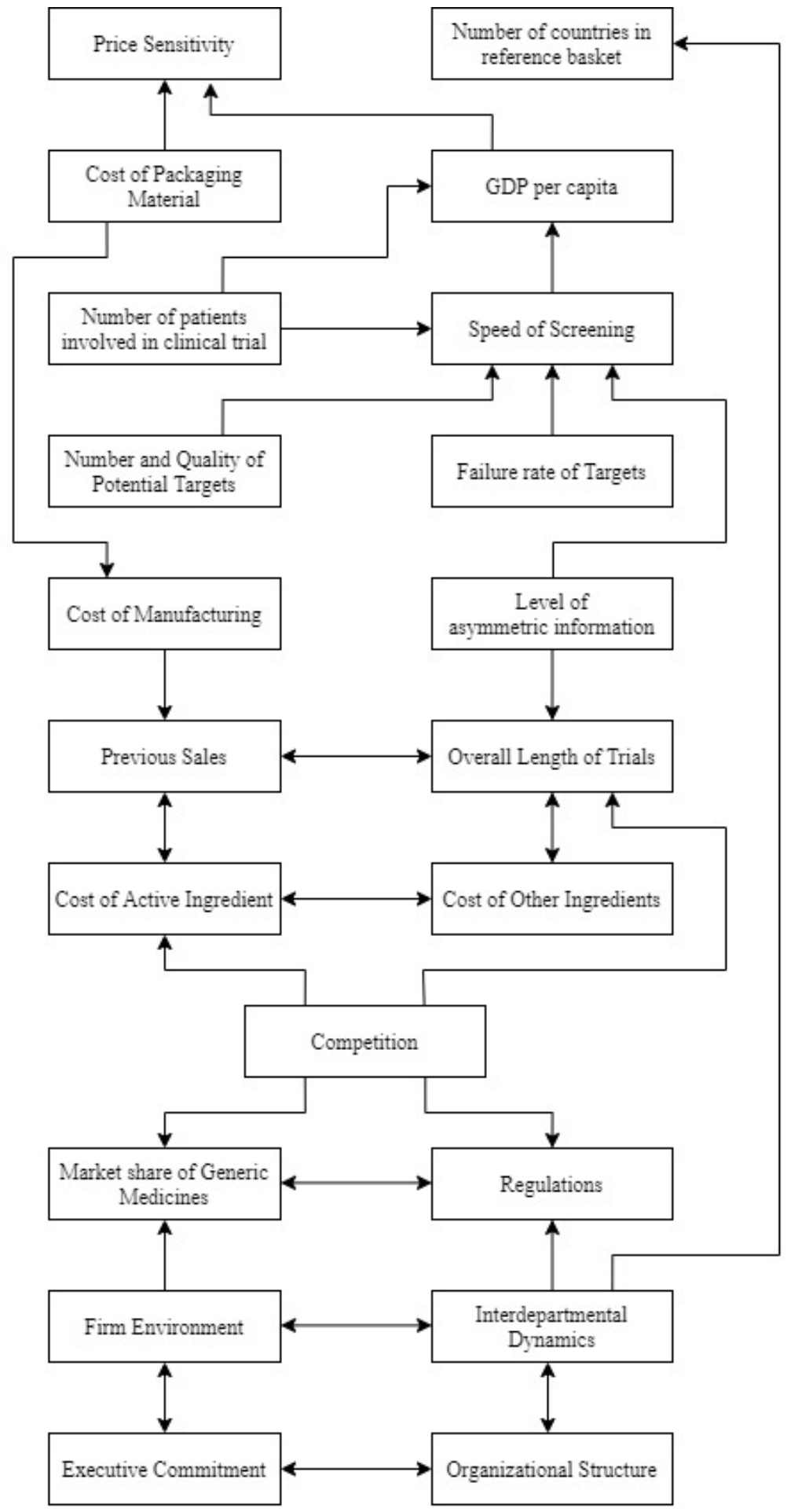

Figure 2: The Final ISM Structure. 


\section{CONCLUSIONS}

The study conducted above involved 5 factors, which were further broken down into 21 variables. The 21 variables were subjected to Interpretive Structural Modeling to study come up with a holistic view of their effects on each other. Based on their driving power and their dependence, MICMAC analysis was done and the variables belonging to the four quadrants have been grouped in their respective cluster. The following conclusions have been drawn from the analysis done.

Cost of the Active Ingredient, Regulations existing in a country or region, and Market Share of Generic Medicines fall under linkage variables, and they need to be studied carefully. If these variables are affected, the entire system will be affected easily.

The number of patients involved in clinical trials, number of countries in the reference basket, number of quality and potential targets, and the failure rate of the targets does not significantly affect the pricing decision of a pharmaceutical drug.

Organization Structure, Firm Environment, Competition, and Executive Commitment greatly influence the presence of data-driven decision making in a pharmaceutical company. This capability is of foremost importance while trying to fix the price of a drug. The culture of the organization must be such that accurate data is maintained.

\section{SCOPE FOR FURTHER RESEARCH}

This study involved finding the relationship between the various variables contributing to the price of a pharmaceutical drug. Further study can be done on the strategies that can be used for each of these variables, to ensure a desirable result. The variables included in this research are not exhaustive, and there are many more variables that can be added for analysis as well.

\section{REFERENCES}

1. Yudatama, Uky \& Hidayanto, Achmad \& Nazief, Bobby. (2018). Approach Using Interpretive Structural Model (ISM) to Determine Key Sub-Factors at Factors: Benefits, Risk Reductions, Opportunities and Obstacles in Awareness IT Governance. Journal of Theoretical and Applied Information Technology. 96. 5537-5549.

2. Sleep, S., Hulland, J., \& Gooner, R. A. (2019). THE DATA HIERARCHY: factors influencing the adoption and implementation of data-driven decision making. AMS Review.

3. Gnanavel, G., and P. Muthusamy. "Pharmaceutical Industry Wastewater Treatment Using Atmospheric Air and Pure Oxygen."IASET: International Journal of Metallurgical, Materials and Chemical Engineering (IASET: IJMMCE) Vol. 7. 6, Oct - Nov2018; 1-6

4. Chiesa, V. and Toletti, G. (2003). How biotechnology changes pharma $R$ \& D: a managerial perspective. Int. J. Biotechnology, Vol. 5, No. 2, pp.125-140.

5. Khoso, Imamuddin \& Ahmed, Rizwan \& Ahmed, Jamshaid. (2014). Pricing strategies in pharmaceutical marketing. The Pharma Innovation Journal. 3. 13-17.

6. Leopold, Christine \& Vogler, Sabine \& Mantel-Teeuwisse, A.K. \& Joncheere, Kees \& Leufkens, H.G.M. \& Laing, Richard. (2012). Differences in external price referencing in Europe-A descriptive overview. Health policy (Amsterdam, Netherlands).104. 50-60. 
7. Ranga, Abhishek. "Firm Efficiency and Stock Returns: Evidence From Indian Pharmaceutical Industry A Data Envelopment Analysis Approach." Management (IJFM) 2.4 (2013): 15-20.

8. Vogler, S., Schneider, P., \& Zimmermann, N. (2019). Evolution of Average European Medicine Prices: Implications for the Methodology of External Price Referencing. PharmacoEconomics.

9. Dylst, Pieter \& Simoens, Steven. (2011). Does the Market Share of Generic Medicines Influence the Price Level?. PharmacoEconomics.29. 875-882.

10. Sekhar, Gv Satya. "A Diagnostic View of Indian Pharma Industry-Need for Clinical Approach." International Journal of Business and General Management 1.1 (2012): 33-39.

11. Renganathan, R. \& CVB, C.Vijayabanu \& Srinivasakumar, V. \& Anand, V. (2016). Pharmaceutical pricing policy and control: Indian perspective. Asian Journal of Pharmaceutical and Clinical Research. 9. 305-308.

12. Mohideen, OM Haja, and M. Parveen. "A Study on Predicting Financial Performance Using Duo Pont Analysis in Cipla Pharmaceutical Company." International Journal of Accounting and Financial Management Research (IJAFMR), ISSN (P) (2014): 2249-6882.

13. Merkuryeva, Galina \& Valberga, Aija \& Smirnov, Alexander. (2019). Demand forecasting in pharmaceutical supply chains: A case study. Procedia Computer Science. 149. 3-10. 

